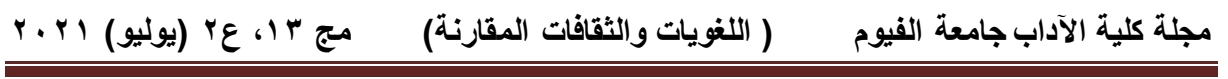

\title{
Analysis of the Biased Language Based on Two Selected Editorial Reports in Light of the Appraisal Theory
}

\author{
Ghada Khaled Mohamed Atalla \\ Prof. Nabila Ali Marzouk ${ }^{1}$ \\ Prof. Abdel Fatah AbdEl Halem Moftah ${ }^{2}$
}

\begin{abstract}
The current research scrutinizes controversial topics that have not been widely discussed before. It is concerned with controversial issues in the Middle East and the West and how these events are related to famous politicians as represented in the western media. Through reviewing different editorial articles about the Middle East and the West, the researcher noticed that the editors handled the controversial events related to famous politicians in a different way. They handle the issues according to their ideologies and cultures. That was obviously noticed when the researcher reviewed various articles in different newspapers related to two politicians: the Iranian General Qassem Soleimani and the former President of the United States of America George Walker Bush. Thus, the aim of the research is to explore the biased language from the linguistic point of view and offers systematic categorization of
\end{abstract}

${ }^{1}$ Professor of English Literature- Faculty of Arts- Fayoum University

${ }^{2}$ Professor of Linguistics - Faculty of Arts- Suez Canal University

(Analysis of the Biased Language...) Ghada Khaled Mohamed Atalla 
particular types of evaluation. As for the method of analysis, this research adopts the Appraisal Theory focusing on the attitude resource with its three sub-systems. The deduction of the research is that news is a representation of editor's ideologies and it portrays their political, personal and national inclination in spite of their claim to be unbiased and neutral in their approach.

Keywords: Appraisal Theory, Attitude, Biased, Ideology, Editorial Articles.

\section{Introduction}

The current research focuses on the evaluative language used in the selected editorial reports handling some controversial issues and famous politicians in the Middle East and West. There will be a detailed analysis of every evaluative item in the editorials. Moreover, the research is more oriented towards exploring and analyzing the linguistic realization of attitudes and evaluations regarding two famous politicians in the Middle East and the West. There is one editorial article deals with the former President of the United States of America George Walker Bush. The other report deals with the Iranian General Qassem Soliemani assassinated in Iraq. The analysis of these reports focuses on the ideological perspective of the West using biased language for describing the previously mentioned characters. Thus, the researcher can make an academic comparison between the famous politicians in the Middle East and the West with respect to the ideologies of the western press.

(Analysis of the Biased Language...) Ghada Khaled Mohamed Atalla 


\section{Report (1): The Former President of the United States of America: George Walker Bush Context of Report}

The first editorial is about the $43^{\text {th }}$ former President of the United States of America: George W. Bush. He holds a variety of public perceptions regarding his policies, personality, and performance as the President of U.S. In the United States, journalists, polling organizations, and others have documented the expression of an evolving array of opinions of President Bush. For example, Time magazine named George W. Bush as its Person of the Year for 2000 and 2004 recognizing him as the most influential person during the previously mentioned years.

The following online editorial, which is Forbes, showed the presidency of George W. Bush as an impressive period of political leadership in 2002. He was able to overcome the skepticism of the professional military in the United States, the opposition of much of the world, and the lack of support from the UN Security Council and take the United States to war with Iraq in order to depose Saddam Hussein.

Over this period, President Bush has various patterns of behavior that point out some insight into his policy preferences. He has shown a preference for moral certainty over strategic calculation; a tendency for visceral reaction rather than reflection; a preference for clarity rather than complexity; a bias toward action rather than deliberation; and a preference for the personal over the structural or procedural. Bush manifested confidence and moral

(Analysis of the Biased Language...) Ghada Khaled Mohamed Atalla 
certainty and exhibited no evidence of self-doubt or ambivalence about major decisions. To conduct a detailed evaluative analysis, each editorial article is divided into three sections: the headline, the lead, and the body. The following analysis defines the evaluation patterns of the Appraisal Theory according to Martin and White's categorization through focusing on the attitude element with its subsystems.

\subsection{Analysis of the Headline}

Headlines are actually the most important part of any article. They attract the readers' attention and mirror the ideological perspectives of their authors and the agency as well. Headlines can be considered as the bridge between the readers and the article content. Thus, the following part will focus on analyzing the headline of the editorial article to identify the evaluative items in light of the attitude category with its subsystems in the Appraisal Theory. The editorial is about the presidency of George W. Bush, his role in Africa, and with the Arabs as a President of U.S.A.

In Forbes, the author used the expression: "War on Terrorism" to attract the reader's attention to the importance of the efforts exerted by the President George W. Bush to fight terrorism, however, there were other persons who were against his policy. Moreover, the headline includes explicit evaluative lexis and that is extended to the article's body. Starting from the title and throughout the article, the author did his best to prove how good

(Analysis of the Biased Language...) Ghada Khaled Mohamed Atalla 
the President George W. Bush was and to persuade the readers with such ideology.

\subsection{Analysis of the Leads}

The lead is the first and the most important sentence in any article. When it is written well, it catches the reader's eyes to continue reading the article. The following is an analysis of the leads mentioned in the three editorial articles.

1. In Forbes, Tom Basile glorified the former President George W. Bush and his policy during his period in the White House although this article was written after six years of leaving The White House. The author depended on the first-person lead as he used the pronoun "Our" to make the reader as a part of the article. He also used the subjective tone and judged the situation that the President George W. Bush is a responsible character who can be depended on against terrorism by using the verb "counted on". He tried to arouse the reader's emotions regarding the difficulty of the situation, but George W. Bush can be considered as a fighter.

\subsection{Analysis of Attitude in the Report Body of the Articles}

The analysis of the report body in the handled editorial articles focuses on the evaluative items in light of the Appraisal Theory in relation to the attitude category and its sub-systems.

(Analysis of the Biased Language...) Ghada Khaled Mohamed Atalla 


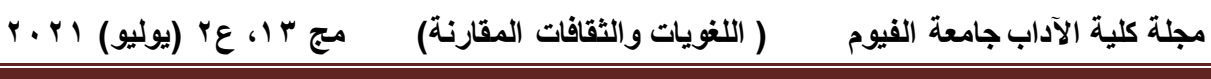

\subsubsection{Affect}

The affectual items in each report are lexical-grammatical values. Based on the analyzed three reports, the authors depended on evaluative lexical items to cover various ideologies regarding the same theme which is the distinguished presidency period of George W. Bush.

\section{In Forbes, they can be classified into the following}

\section{1) Nominal}

Leaders like Mummar el Gaddafi were shaking in their boots.

\section{2) Verbal}

While Obama and Democrats in Congress lamented that U.S. policy had made us unpopular on the world stage.

In the first editorial article in Forbes, the authorial voice is subjective. He tried to show the continuous efforts of the President George W. Bush to overcome terrorism. Moreover, he intentionally criticized the policy of the President Barack Obama to highlight the wisdom of the previous President George W. Bush and to control the reader's perspective in an emotional way.

The author used the direct negative behavioral affect when he described the Obama's and Democrats' feeling during the presidency period of Barack Obama, however, he used the direct positive behavioral affect while describing not only the emotions of American but also the emotions of the whole people around the world during the presidency period of George W. Bush: "While

(Analysis of the Biased Language...) Ghada Khaled Mohamed Atalla 


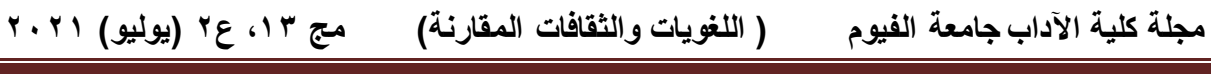

Obama and Democrats in Congress lamented that U.S. policy had made us "unpopular" on the world stage, Bush's strategy helped keep not only Americans, but perhaps billions more around the world safe."

Moreover, he used the sarcastic direct negative affect when he described the leaders, especially, President Muammar Gaddafi to show that they were afraid with unstable emotions while the American troops were on the Iranian border to show President George W. Bush as a hero with a strong policy: "We had American troops on both sides of the Iranian border. Leaders like Muammar Gaddafi were shaking in their boots".

Basile pursued highlighting the heroism of the previous President George W. Bush through criticizing the policy of the President Barack Obama and his relationship with the Arabs depending on the direct negative affect as in the following statements: (1) "In relentlessly driving his domestic agenda, most often unilaterally leveraging the power of the Executive Branch, Obama has demonstrated he understands the nature of the insurgent. Still, he equivocates and tempers his response to terrorism", (2) "While the Obama White House tried to convince Americans that the so-called Arab Spring was a validation of the President's softer approach, instability was growing throughout the region. ", and (3) "Obama scarcely mentions Libya despite the fact that the Administration is largely to blame for the instability there. Unlike Bush in Iraq, Obama didn't believe we had any

(Analysis of the Biased Language...) Ghada Khaled Mohamed Atalla 
moral obligation to invest time, money and people into building new political institutions and stability after helping to decapitate the regime.

\subsubsection{Explicit Judgment}

Like any attitudinal subsystem, values of judgment can be realized either explicitly or implicitly. Linguistically, judgment can be expressed positively or negatively through five subtypes. According to the analysis of the selected editorials, judgment resources are recognized through:

- In Forbes:

\section{Capacity: how capable?}

He believed and his policy reflected that this is a global threat from dozens of groups--not just Al Qaida or ISIS-that will stop at nothing to kill as many people as they can.

\section{Propriety: how good they are?}

After systematically dismantling years of work and marginalizing the sacrifice of countless Americans who fought the War on Terrorism during the Bush years, he's now flailing to articulate some semblance of an anti-terror policy.

Second, this terror threat must be met with overwhelming force because it is a growing international movement which will either be destroyed on foreign soil or will hit us again here at home.

(Analysis of the Biased Language...) Ghada Khaled Mohamed Atalla 


\section{Tenacity: how dependable someone is?}

He believed and his policy reflected that this is a global threat from dozens of groups--not just Al Qaida or ISIS--that will stop at nothing to kill as many people as they can.

\section{Normality: how special someone is?}

- It's a peculiar position for an American Progressive like Obama who considered Saul Alinsky a great influencer.

* "Keep the pressure on. Never let up."

\section{Veracity: how honest someone is?}

* Iraq, for better or worse, may have become the perceived core of his War on Terror, but in reality it was only a piece of a much larger, global strategy that was hunting, disabling and killing terrorists every day.

Explicit judgment is usually exploited in editorials as the writers are subjective most of the time and they try to cover a certain direct message to the readers according to their points of view. In Forbes, the author depended mainly on judgment throughout the article to persuade the reader with one issue; how special was the previous President George W. Bush in dealing with terrorism.

The author proved that by mentioning another president's words: the French President Francois Hollande as he was against the President Obama's policy. Thus, he used the direct negative judgment: "French President Francois Hollande directly countered Obama's own words in his address to Parliament

(Analysis of the Biased Language...) Ghada Khaled Mohamed Atalla 
Monday saying of the fight against ISIS, "It's not about containing. It's about destroying this enemy". This is also clear through using the direct positive judgment and the negative one to ensure the good intentions of Americans against the bad ones of the Islamic Movement: "Two distinct but related battles are being waged here. One is between the values of freedom, tolerance and participatory government against the international radical Islamist movement".

Throughout the editorial article, the authorial voice is the only dominant voice depending on the direct negative judgment including, either social sanction or social esteem, and a rare number of direct positive judgmental lexis to impact the reader's way of thinking regarding the wise policy of George W. Bush against terrorism. This is achieved by comparing between the presidency period of two different presidents; George W. Bush and Barak Obama as it follows:

- "Bush saw the distinction between the terrorist ideology and freedom in very stark terms. He believed and his policy reflected that this is a global threat from dozens of groups--not just Al Qaida or ISIS--that will stop at nothing to kill as many people as they can. Iraq, for better or worse, may have become the perceived core of his War on Terror, but in reality it was only a piece of a much larger, global strategy that was hunting, disabling and killing terrorists every day. He understood that the environment

(Analysis of the Biased Language...) Ghada Khaled Mohamed Atalla 
that aids terror leaders in radicalizing stems from a lack of freedom and opportunities for advancement in many societies."

- "He was derided as an alarmist for suggesting that these radical Islamists wanted to turn Iraq or another country into a caliphate. He was compared to Hitler and branded a war criminal by prominent American thought leaders, media personalities and politicians."

Furthermore, the author tried to describe the situation in Iraq from his own point of view after the previous President George W. Bush had left the White House. He did so by using both positive and negative explicit direct judgment and concentrating on Obama's policy. This can be obvious in the following examples:

- "Local populations were working together with Coalition and Iraqi forces against foreign fighters and terror groups".

- "Our allies knew that George W. Bush could be counted on to fight this enemy".

- "Obama's view of the world is either grounded on fanciful notions of the power of his own personal magnetism or just a willful blindness to just how wrong he was about the very nature of the role the U.S. plays on the world stage."

(Analysis of the Biased Language...) Ghada Khaled Mohamed Atalla 
- Today, the President still won't label this effort as a war against radical Islamic extremism ".

In addition, the author elaborated on praising the efforts of the previous President George W. Bush and considered himself as a part of the White House by repeating the pronoun "We". On the other hand, he bitterly criticized President Obama as if he did nothing for the Americans because of his policy against terrorism. He depicted the previous President George W. Bush as a man of actions, but the President Obama as a man of words only. This is stated below using explicit judgment:

- "We've released dozens of high-value terrorists from Guantanamo Bay, despite the fact that members of the U.S. military were injured or even killed to capture them. "

- "Since Obama failed to support the duly-elected government in Libya after the fall of Gaddafi, ISIS and other terror are today closer than ever to gaining outright control over the oil, infrastructure and other resources of Libya giving terror another foothold from which to attack Europe."

- "Unlike Bush in Iraq, Obama didn't believe we had any moral obligation to invest time, money and people into building new political institutions and stability after helping to decapitate the regime.

(Analysis of the Biased Language...) Ghada Khaled Mohamed Atalla 
- George W. Bush understood that there is no such thing as universal values. The reality of our world is that there are people and movements that don't share our values and will seek to subjugate or destroy those who hold our values."

- America needs to wake up and realize that while the Bush Administration wasn't without its mistakes and missteps, the model George W. Bush developed for fighting this real global War on Terrorism is the only way to address the threat we face."

\subsubsection{Appreciation}

Unlike judgment, appreciation system is used to evaluate natural phenomena, process, and abstract things. The values of appreciation are divided into three subcategories: reaction, composition, and valuation.

In the analysis of the three editorials, grammatically, appreciation values can be realized as:

\section{- In Forbes:}

\section{Adjective:}

- To be fair, Republicans for their part have spent so much time running away from many of the policies of the Bush Administration, they are now faced with bringing murky proposals for interdicting terrorism into more specific relief 
- The other is an ideological fight between the Bush and Obama anti-terror strategies and indeed both men's view of the world in which we live.

\section{Adverbial:}

- In relentlessly driving his domestic agenda, most often unilaterally leveraging the power of the Executive Branch, Obama has demonstrated he understands the nature of the insurgent.

\section{Verb:}

- The American President is rhetorically groping his way through crisis yet again, trying in vain to sound tougher at a time when the "JV team" is flooding Europe with refugees and Jihadists.

\section{Nominal:}

- After systematically dismantling years of work and marginalizing, the sacrifice of countless Americans who fought the War on Terrorism during the Bush years, he's now flailing to articulate some semblance of an anti-terror policy.

In Forbes, the author exploited appreciation and its different types throughout the editorial article to have a certain effect on the readers. The appreciation appeared at the beginning of the article at the first statement to attract the reader's attention when he described the President Barak Obama as a spinning top: "President Barack Obama is spinning like a top". In the previous

(Analysis of the Biased Language...) Ghada Khaled Mohamed Atalla 
example, the author used the indirect negative appreciation to point out that President Barak Obama is not with an obvious policy. In addition, he used the direct positive and negative appreciation to portray that Bush's efforts against terrorism were lost because of the President Obama's way of thinking:

- "After systematically dismantling years of work and marginalizing the sacrifice of countless Americans who fought the War on Terrorism during the Bush years, he's now flailing to articulate some semblance of an anti-terror policy.

- "The American President is rhetorically groping his way through crisis yet again, trying in vain to sound tougher at a time when the "JV team" is flooding Europe with refugees and Jihadists."

Furthermore, the author showed that Americans were against Obama's policy against terrorism. There was also an argument regarding the way of dealing with the terrorism issue in the presidency periods of the previous President Bush and the President Obama. This was demonstrated through using the direct appreciation either positive or negative as in the following examples:

- "This week, half of the governors in the United States have refused to allow resettlement of Syrian refugees within their borders."

(Analysis of the Biased Language...) Ghada Khaled Mohamed Atalla 
- "The other is an ideological fight between the Bush and Obama anti-terror strategies and indeed both men's view of the world in which we live."

- "Bush saw the distinction between the terrorist ideology and freedom in very stark terms."

- "He was condemned as an imperialist for pursuing a broad strategy of active deterrence using all the assets provided to him by the U.S. government be they diplomatic, political, economic or military."

In fact, the dominant authorial voice is subjective, however, in the following examples the author relied mainly on the direct positive and negative appreciation and tried to be subjective to affect the reader's ideology regarding the two presidents: George W. Bush and Barak Obama as described below:

- "To be fair, Republicans for their part have spent so much time running away from many of the policies of the Bush Administration, they are now faced with bringing murky proposals for interdicting terrorism into more specific relief."

- "President Bush's Administration conducted anti-terror operations, in more than 160 countries in conjunction and with the cooperation of governments around the world.

- "While Obama and Democrats in Congress lamented that U.S. policy had made us "unpopular" on the world stage, 
Bush's strategy helped keep not only Americans, but perhaps billions more around the world safe."

The author then continued using the appreciation lexical items to criticize Obama's policy in the Middle East and against terrorism to be different from the previous President Bush. According to the author's perspective, this change badly affected the Americans' situation. This ideology is stated as following:

- "In relentlessly driving his domestic agenda, most often unilaterally leveraging the power of the Executive Branch, Obama has demonstrated he understands the nature of the insurgent."

- "Our abandonment of Iraq allowed ISIS to not only form but take control of much of the country."

- "The work we had done in Yemen for more than a decade was allowed to collapse.

\section{Report (2): Qassem Soleimani "the Iranian General"}

\section{Context of Report}

The second editorial is about the Iranian General Qassem Soleimani. He was the Iranian major general and commander of the Quds Force from 1997 till 2020, a wing of the Islamic Revolutionary Guard Corps (IRGC) responsible for the corps' foreign operations.

In recent years, Iran has established its power across the Middle East, from Lebanon and Syria to Iraq and Yemen. One of the keys to its success was the unique strategy of blending militant and

(Analysis of the Biased Language...) Ghada Khaled Mohamed Atalla 
state power, built in part on the model of Hezbollah in Lebanon. The well-known principal architect of this policy was Major General Qassem Soleimani, the long-serving head of Iran's Quds Force. Soleimani was actually considered the most powerful general in the Middle East. In addition, He was one of Iran's most popular living people and was repeatedly touted as a possible presidential candidate.

The following online editorial, which is New York Post, imaged Soleimani as a killer. The editorial tried to prove one reality which is he was responsible for killing many American soldiers in Iraq. He was also described as a terrorist as he helped others to kill women, children and men in Syria.

To carry out a detailed evaluative analysis, the editorial article is divided into three sections: the headline, the lead, and the body. The following analysis defines the evaluation patterns of the Appraisal Theory according to Martin and White's categorization through focusing on the attitude element with its subsystems.

\section{Y.1. Analysis of the Headline}

The importance of headlines was mentioned previously in Set I as they attract the readers' attention and mirror the ideological perspectives of their authors and the agency as well. Thus, the following part will focus on analyzing the headlines of the three editorial articles to identify the evaluative items in light of the attitude category with its subsystems in the Appraisal Theory. The editorial is about the Iranian General Qassem Soleimani.

(Analysis of the Biased Language...) Ghada Khaled Mohamed Atalla 
1. In New York Post, the author used the word: "Cheering" to attract the reader's attention to one fact which is the incident of Soleimani 's death was like a festival that should be celebrated. It was an indication to the readers that he deserved that without any excuses.

\subsection{Analysis of the Leads}

The role played by the lead was mentioned previously in Set I as it is the first and the most important sentence in any article. The following is an analysis of the leads mentioned in the three editorial articles.

1. In New York Post, there is no lead. The writer depended on starting the article with a strong word which is "Cheering". Then, He paraphrased the headline again in the first sentence of the article with mentioning the reason of cheering which is the death of the terrorist Soleimani.

\subsection{Analysis of Attitude in the Report Body of the Articles}

The analysis of the report body in the handled editorial article focuses on the evaluative items in light of the Appraisal Theory in relation to the attitude category and its sub-systems.

\subsubsection{Affect}

The affectual items in the report are lexical-grammatical values. Based on the analyzed report, the author depended on evaluative

(Analysis of the Biased Language...) Ghada Khaled Mohamed Atalla 
lexical items to cover other ideologies regarding the same theme which is the Iranian General Qassem Soleimani and terrorism.

- In New York Post, they can be classified into the following:

1) Nominal

Cheering the death of Qassem Soleimani — no ifs, ands or buts.

\section{2) Verbal}

Soleimani's forces killed at least 608 US troops in Iraq from 2003 to 2011, the Pentagon reported last year - and that doesn't include those killed then and since by the many proxies under his control.

Throughout the first editorial article in New York Post, the dominant voice is the author's voice. The author supposed one fact and tried to persuade the readers with it which is that Soleimani was a terrorist and the world celebrated his death. Thus, he used the affective words, either positive or negative, to influence the readers' feelings. According to the text, Soleimani participated in the death of hundreds of innocent people and he was considered as a threat to the American's security. Hence, Trump's decision to get rid of him was the most appropriate solution to help the world and especially the Americans. This can be traced in the following examples:

- $\quad$ It was supposed to be just another day at the office for the commander of the Islamic Revolutionary Guard Corps' Quds Force - but a MQ-9 Reaper drone ended his decades-long killing spree in a hit President Trump ordered on his convoy at Baghdad's airport."

(Analysis of the Biased Language...) Ghada Khaled Mohamed Atalla 
- "Soleimani's forces killed at least 608 US troops in Iraq from 2003 to 2011, the Pentagon reported last year - and that doesn't include those killed then and since by the many proxies under his control."

- "So you'd think the humanitarians of the left would cheer the demise of this butcher, as the right united in applauding President Barack Obama's 2011 hit on Osama bin Laden."

- $\quad$ "There is no question that Qassem Soleimani was a threat to [our] safety and security. ... But there are serious questions about how this decision was made," intoned Pete Buttigieg.\}

- "He “was responsible for directing Iran's destabilizing actions in Iraq, Syria and throughout the Middle East, including attacks against US forces."

\subsubsection{Explicit Judgment}

As mentioned before in Set I, values of judgment can be shown either explicitly or implicitly and can be expressed positively or negatively through five subtypes. According to the analysis of the selected editorials, judgment resources are recognized through: In New York Post:

\section{Capacity: how capable?}

Yes, Iran's rulers may sponsor some atrocity in the name of revenge for Soleimani — but only by using terror networks he was crucial to building, networks it has always

(Analysis of the Biased Language...) Ghada Khaled Mohamed Atalla 
intended to use at a time of its choosing. And that's the only "but" that matters here.

\section{Propriety: how good they are?}

He had nearly that many Iraqis killed in the final months of 2019, ordering a brutal crackdown on protests against a corrupt, Tehran-dominated government.

\section{Tenacity: how dependable someone is?}

* The monster "was a murderer, responsible for the deaths of thousands, including hundreds of Americans. But this reckless move escalates the situation with Iran," tweeted Sen. Elizabeth Warren - leaving out the fact Soleimani was about to escalate by having more Americans killed.

So you'd think the humanitarians of the left would cheer the demise of this butcher, as the right united in applauding President Barack Obama's 2011 hit on Osama bin Laden.

\section{Normality: how special someone is?}

* That's why crowds took to the streets in the middle of the Tehran night to celebrate his death.

\section{Veracity: how honest someone is?}

Instead, the "but" brigade is out in full force, conceding Soleimani's evil but warning that the world may be worse off because Trump ordered his death.

Explicit judgment is usually exploited in editorials as the writers are subjective most of the time and they try to cover a certain direct message to the readers according to their points of

(Analysis of the Biased Language...) Ghada Khaled Mohamed Atalla 
view. In New York Post, the author depended mainly on judgment throughout the article to show that Soleimani deserved to be killed as he was an evil. In addition, he was terrorist and a killer. The author also illustrated that if he was not killed, more destruction would happen all over the world, especially in America. The following examples illustrate that concept through using judgment.

- "One of the world's top terror masterminds is dead, and that's an unalloyed good-no ifs, ands or buts about it."

- "Qassem Soleimani flew from Lebanon to Iraq early Friday to oversee plans to murder more Americans."

- "He helped kill far more at home, with over 1,000 peaceful protesters slaughtered in what Iranians call Bloody November."

- "That's why crowds took to the streets in the middle of the Tehran night to celebrate his death."

- "So you'd think the humanitarians of the left would cheer the demise of this butcher, as the right united in applauding President Barack Obama's 2011 hit on Osama bin Laden."

- The monster "was a murderer, responsible for the deaths of thousands, including hundreds of Americans. But this reckless move escalates the situation with

(Analysis of the Biased Language...) Ghada Khaled Mohamed Atalla 
Iran," tweeted Sen. Elizabeth Warren - leaving out the fact Soleimani was about to escalate by having more Americans killed."

- "Yes, Iran's rulers may sponsor some atrocity in the name of revenge for Soleimani - but only by using terror networks he was crucial to building, networks it has always intended to use at a time of its choosing. And that's the only "but" that matters here."

\subsubsection{Appreciation}

As mentioned in Set I, unlike judgment, appreciation system is used to evaluate natural phenomena, process, and abstract things. The values of appreciation are divided into three subcategories: reaction, composition, and valuation. In the analysis of the three editorials, grammatically, appreciation values can be realized as:

- In New York Post:

1. Adjective:

He helped kill far more at home, with over 1,000 peaceful protesters slaughtered in what Iranians call Bloody November.

\section{Verbal:}

But this reckless move escalates the situation with Iran," tweeted Sen. Elizabeth Warren - leaving out the fact Soleimani was about to escalate by having more Americans killed.

(Analysis of the Biased Language...) Ghada Khaled Mohamed Atalla 


\section{Nominal:}

Yes, Iran's rulers may sponsor some atrocity in the name of revenge for Soleimani — but only by using terror networks he was crucial to building, networks it has always intended to use at a time of its choosing.

Throughout the article, the editorial board made use of strong clear lexical items to image how Soleimani was a devil as he was planning all the time to spread evil in the Middle East and America as well. This is achieved by depending on appreciation and its types to make the image clear to the readers as in the following examples:

- "One of the world's top terror masterminds is dead, and that's an unalloyed good - no ifs, ands or buts about it."

- "Qassem Soleimani flew from Lebanon to Iraq early Friday to oversee plans to murder more Americans."

- $\quad$ "It was supposed to be just another day at the office for the commander of the Islamic Revolutionary Guard Corps' Quds Force - but a MQ-9 Reaper drone ended his decades-long killing spree in a hit President Trump ordered on his convoy at Baghdad 's airport."

- "Soleimani's forces killed at least 608 US troops in Iraq from 2003 to 2011, the Pentagon reported last year - and that doesn't include those killed then and since by the many proxies under his control ."

(Analysis of the Biased Language...) Ghada Khaled Mohamed Atalla 
- "He helped kill far more at home, with over 1,000 peaceful protesters slaughtered in what Iranians call Bloody November."

\section{Commentary on the Analysis:}

By reviewing studies related to controversial issues, mainly politics, the researcher found out that these studies used the Appraisal Theory and evaluative language in order to attract the reader's attention, convey a certain message, uncover the hidden meaning and reveal the hidden hegemony and power resulting from different ideologies and cultures. To conduct a detailed evaluative analysis, each study of the following applied the attitude subsystem. The following analyses define the evaluation patterns of the Appraisal Theory according to Martin and White's categorization through focusing on the attitude element with its subsystems. The researchers of these selected studies found out that, through analyzing the data they chose, the speakers or the writers of these materials used evaluative items to persuade the readers with their point of view and to convey a certain message. This supports the idea of the researcher of the current study regarding using the Appraisal Theory as a method to identify the hidden ideologies of the writers, to attract reader's attention and to deliver a hidden message.

Politicians use a range of techniques, tactics and strategies to appeal their audience. Firola Muliza (2008) used the Appraisal Theory focusing on attitude subsystem in the study, Political

(Analysis of the Biased Language...) Ghada Khaled Mohamed Atalla 
Discourse of PM Theresa May: An Appraisal Analysis, to analyze political speech and uncover the hidden meaning of it. Therefore, this study aims to find the attitude resource of the Appraisal Theory (Affect, Judgment, and Appreciation) in the speech of Theresa May, the Prime Minister of the United Kingdom, and how those devices are used to convey the intention of the Prime Minister.

The Prime Minister of the United Kingdom tried to appeal the public of Northern Ireland, by using positive words, to believe that they have the same achievement in which created a context that government and public can work even better if united.

- $\quad$ Our sense of community and shared values. Our diversity and tolerance $\}$

- $\quad$ And perhaps the greatest strength of our Union is its potentialfor the future.\}

By appraising the country with words such as diversity and tolerance, May tried to put the country in favorable light. According to the analysis of the study, the appreciation items were positive. There are 45 positive appraising expressions and only 10 negative appraising expressions within the speech. The dominance of appreciation subsystem is because a leader of political stances must first evaluate things when it comes within the political territory. This evaluation of thing serves to mirror the prime minister's leadership skill: on how she responds to a

(Analysis of the Biased Language...) Ghada Khaled Mohamed Atalla 
situation correctly and creates an effective policy fitting the evaluation.

Judgment is the second element in the speech. In the first subtopic, May aligned herself not only as a representative of British government, but also as a member of a country who pay tribute to the lives that were lost in the civil war in Northern Ireland. The intention is not only to sympathize by sharing the same sentiment, but also to gain the same sympathy to encourage the people to have faith in the government. There is also a frequent use of lexical word will that occurred almost in every sub-topic

- $\quad$ So a government I lead will never be neutral in our supportfor the Union.\}

- II will always govern in the interests of the whole community in Northern Ireland and not just one part of it.\}

Affect, the last subsystem of the attitude resource. There is no much usage of affect in the speech of the Prime Minster. The lack usage of affect can be due to their formal speech and their preference to cast off the impression that they are too emotional in a formal event. Instances of affect are exemplified below:

- $\quad$ But I also respect the fact that a substantial section of the population here identify as Irish and aspire to a future within a united Ireland.\}

- SWe want to work with all parties and right across society to build a stronger, more inclusive and more

(Analysis of the Biased Language...) Ghada Khaled Mohamed Atalla 
prosperous Northern Ireland that truly works for everyone.\}

Ding Ailan (2017) aimed at analyzing attitudinal resources in Obama's victory speech from perspective of the Appraisal Theory. The researcher used the attitude resource to discover how the subsystems of Affect, Judgment and Appreciation are applied to attract the audience, arouse their sympathy, rebuild public confidence, minimize hostility and appeal to the public for national solidarity.

The first subsystem of the attitude resource is affect. According to the researcher of the study, the subsystems of affect in this speech have been achieved through the analysis. The president's cheerful mood extends the whole speech which can be felt when the president talks about his partner, family and the good times. Also, through the speech, Obama shows his concern with security problems, economic depression and people's living conditions and expresses his desire to serve the interests and needs of lower-class people. According to his speech, these problems will be his top priority in the future administration. This can be traced in many examples in the speech as following:

- $\quad$ And I would not be standing here tonight without the unyielding support of my best friend for the last 16 years, the rock of our family, the love of my life, the nation's next first lady, Michelle Obama.\}

(Analysis of the Biased Language...) Ghada Khaled Mohamed Atalla 
- $\quad$......We cannot have a thriving Wall Street while Main Street suffers.\}

- $\{$...but America, I have never been more hopeful than I am tonight that we will get there.\}

- $\quad$ The road ahead will be long. Our climb will be steep. We may not get there in one year or even in one term, but America, I have never been more hopeful than I am tonight that we will get there.\}

The second section of Ailan's analysis is judgment resources in Obama's Victory Speech. Obama used resources of judgment to glorify the great role of his people and his team and justify his decisions as the head of government. Obama tried to appeal his people to do what they can to maintain peace, promote democracy and justifies the righteousness of their pursuit for peace, democracy, progress, quality, security and prosperity. Meanwhile, he condemns the viciousness of tyranny, war, inequality and discrimination and political misconduct. This can be stated in a number of examples in the article as it follows:

- WWhen there was despair in the Dust Bowl and depression across the land, she saw a nation conquer fear itself with a New Deal, new jobs, a new sense of common purpose. Yes, we can.\}

- $\{$ And I would not be standing here tonight without the unyielding support of my best friend for the last 16 years,

(Analysis of the Biased Language...) Ghada Khaled Mohamed Atalla 
the rock of our family, the love of my life, the nation's next first lady, Michelle Obama.\}

In the analysis of victory speech, the third subsystem of the attitude resource is appreciation. Appreciation is concerned with the evaluation of abstract things such as policies, plans, and natural objects. Through the speech, resources of Appreciation are related to emotional responses of audiences, the quality of the campaign and the campaign team, social significance of the American Dream, the American ideals as well as the spirit of patriotism, responsibility, self-reliance and national unity. The following examples are appreciations extracted from the victory speech:

- That the true genius of America, that America can change.\}

- $\quad$ Let us resist the temptation to fall back on the same partisanship and pettiness and immaturity.\}

- $\quad$ And to my campaign manager, David-the unsung hero of this campaign who built the best political campaign.\}

According to Ailan's study, the Analysis of Attitudinal Resources in Obama's Victory Speech from Perspective of Appraisal Theory, resources of affect, positive ones make up $65.2 \%$ of the total number which coincides with the hopeful and optimistic tone of this victory speech. In the victory speech, Obama wanted to deliver a certain message and showed his optimism about American's future in spite of temporary challenges and difficulties. Judgment, both resources of Social

(Analysis of the Biased Language...) Ghada Khaled Mohamed Atalla 
Esteem and Social Sanction take up 50\%. Positive resources are used to justify the cause of promoting peace, democracy, equality, prosperity and progress. However, negative resources of Propriety are used to condemn the viciousness and immorality of tyranny, violence, terrorism, discrimination and political misconduct. Appreciation resources are all positive and make up a proportion of $51.5 \%$ of the total number. The president speaks highly of the great social significance of the election campaign. The president foregrounds the great social significance of the American Dream which is used as a uniting concept to foster national solidarity and restore public morale. The president emphasizes the importance of traditional values of patriotism, responsibility, self-reliance and national unity. He highlights the power of faith and hope to stir his people's passion to work wonders. He emphasizes the power of democracy by clearly exhibiting his strong sense of superiority of a super-power.

Li Qi (2017) applied the Appraisal Theory from other angle. The researcher applied positive discourse analysis (PDA) under the framework of appraisal theory in her study, Positive Discourse Analysis of Hillary Clinton's Concession Address, to focus on the deconstruction of society and peaceful solution to the problems.

Through the analysis of the speech, Clinton depended on variety of attitude resources in her speeches to interact with audience and construe positive relation with them. Li Qi found that there are a total of 36 attitude resources adopted in the

(Analysis of the Biased Language...) Ghada Khaled Mohamed Atalla 
concession address and 14 appreciation resources. The negative appreciation only appears once, outnumbered by positive appreciation. The following examples are showing how Hillary uses positive appreciation to her campaign and her strong supporters, the Obamas.

- $\quad$ Being your candidate has been one of the greatest honors of my life.\}

- $\quad$ To Barack and Michelle Obama, our country owes you an enormous debt of gratitude. We thank you for your graceful, determined leadership.\}

Affect is used to express the speaker's feeling. There are 11 affect resources in this study. In her concession address, Hillary employs many positive affect resources to express her gratefulness to be involved in this campaign, and only a few negative affect resources to show her disappointment. The following examples are taken from the speech:

- $\quad$ \{I'm so grateful to stand with all of you.\}

- $\quad$ I'm sorry that we did not win this election. $\}$

- $\quad$ I know how disappointed you feel because I feel it too.\}

The last subsystem of the attitude subsystem is judgment. There are nine judgment resources in the speech. Hillary adopts many positive judgment resources to praise those working for the country to invisibly get align with them. This can be seen through the following examples:

(Analysis of the Biased Language...) Ghada Khaled Mohamed Atalla 
- II will always be grateful to the creative, talented, dedicated men and women at our headquarters in Brooklyn and across our country. $\}$

- \{Never doubt that you are valuable and powerful.\}

The findings proved that the application of Appraisal Theory revealed that we can learn how political orators use positive strategies to attract the audience's attention, win their sympathy, and build a harmonious, loving and united society. And through the analysis of concession addresses, we can also learn how language is used to construct society by showing its positive side.

Jinxiu Jin (2019) investigated political news discourse in her study, Political News Discourse Analysis Based on an Attitudinal Perspective of the Appraisal Theory-Taking the New York Times' Report China-DPRK Relations as an Example, to show how discourse plays a vital role to shape the relations between China, the United States and North Korea.

Jinxiu found that there are many negative affect in the report, the first subsystem of attitude, by these negative words the United States has shown that China is acting in its own interest, regardless of the overall situation, on North Korea peninsula issue. The United States, by twisting the facts, aims to destroy China's image and put pressure on China. The United States doesn't want to see the relationship between China and North Korea getting better, so here in the American press, using a word such as suspicions drive a wedge between the China and North Korea and

(Analysis of the Biased Language...) Ghada Khaled Mohamed Atalla 
separate the two countries. This can be obvious in the following examples:

- $\{$ Such an image would seem to bolster Mr. Trump's suggestion that China, angered by American tariffs on its goods, was no longer a partner in the effort to disarm the North.\}

- $\{$ China, they say, still harbors deep suspicions about the North and Mr. Kim, despite the recent thaws in the neighbors' off-and-on relationship.\}

The second subsystem is judgment. It is noticed that the blame in the speech is used to condemn China, and suggest that China is responsible for the Korean peninsula issue. However, the responsibility for the Korean peninsula issue lies mainly with the United States, while the United States puts the responsibility on China. Also, through the speech the American press reported that China punishes North Korea in order to provoke the contradiction between the two countries. Judgment can be traced in many examples in this speech as following:

- $\{$ BEIJING -- When President Trump said on Friday that there had not been sufficient progress toward ridding North Korea of its nuclear weapons, he made it clear that he thought China was partly to blame.\}

- KChina, they say, still harbors deep suspicions about the North and Mr. Kim, despite the recent thaws in the neighbors' off-and-on relationship. And while it is giving

(Analysis of the Biased Language...) Ghada Khaled Mohamed Atalla 
the North some economic help around the edges, they say, China is mostly abiding by the international sanctions meant to punish Pyongyang for its nuclear pursuits. $\}$

Appreciation system is the last system in the attitude system. However, there is almost no positive appreciation resource in the whole speech which indicates America does not appreciate China. We can see in this study the Appraisal Theory was suitable for the analysis the that the idea of the biased language North Korea leader Kim Jong-un frequently visit China which makes the relations between the two countries have been advancing by leaps and bounds. America is unhappy to see this. Therefore, the US is going to damage the relations between the two countries through this report.

- The first article retrieved from:

https://www.forbes.com/sites/thomasbasile/2015/11/20/its-timeto-revisit-george-w-bushs-global-anti-terrorstrategy/\#6be422fcdce5

- The second article retrieved from: https://nypost.com/2020/01/03/cheering-the-death-of-qassem$\underline{\text { soleimani-no-ifs-ands-or-buts/ }}$ 


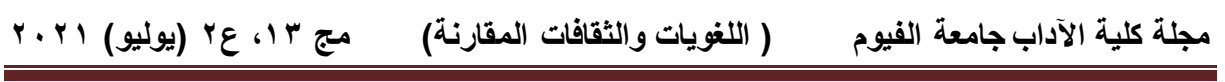

\section{References:}

Ailan, D. (2017) The Analysis of Attitudinal Resources in Obama's Victory Speech from Perspective of Appraisal Theory. Higher Education of Social Science, 12 (1), 37-44.

Jin, J. (2019). Political News Discourse Analysis Based on an Attitudinal Perspective of the Appraisal Theory-Taking the New York Times' Report China-DPRK Relations as an Example. Theory and Practice in Language Studies, 9 (10), 1357-1361. http $/ /$ dx.doi.org/10.17507/tpls.0910.15

Muliza, F. (2018). Political Discourse of PM Theresa May: An Appraisal Analysis. University of Sumatera Utara, Medan.

Qi, L. (2017). Positive Discourse Analysis of Hillary Clinton's Concession Address. Journal of Literature and Art Studies, 7 (10), 1326-1330.

(Analysis of the Biased Language...) Ghada Khaled Mohamed Atalla 


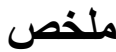

يدرس البحث الحالي الموضو عات المثيرة للجدل و التي لم تتم مناقتتها على نطاق و اسع من قبل. كما أنه يهتم بالقضايا الجدلية في منطقة الثرق الأوسط وفي الغرب وكيف ترتبط هذه الأحداث بالسياسيين ذو الثهرة وكيف يتم الحديث عنهم من قبل الإعلام الغربي. ومن خلال مر اجعة المقالات المحررة المختلفة حول الثرق الأوسط و الغرب ـ وقد لاحظ الباحث أن المحررين تعاملوا مع الأحداث المثيرة للجدل المتعلقة بالسياسيين المشهورين بطريقة مختلفة. فهم يتعاملون مع القضايا وفقًا لإيديولوجياتهم وثقافاتهم. وقد لوحظ ذلك عندما قام الباحث باستعر اض عدد من المقالات في صحف مختلفة تتعلق بسياسيين مشهورين و هما : الجنر ال الإير اني قاسم سليماني ورئيس الولايات المتحدة الأمريكية الأسبق جورج بوش. ومن ثم ، فإن هدف البحث الحالي هو اكتشاف اللغة المتحيزة من وجهة النظر اللغوية وتقديم تصنيف منهجي لأنو اع معينة من التقييه. و بالنسبة لطريقة التحليل ، يتبنى البحث نظرية التقييم التي تركز على الإتجاهات بأنظمته الفرعية التثلاثة. وتوصل البحث إلى أن الأخبار تمثل إيديولوجيات المحرر وتصور ميولهم السياسية والثخصيةو الوطنية على الرغم من ادعائهم عدم التحيز و الحيادية في نهجهم.

الكلمات الدلالية: نظرية التقييم، الإتجاه، الأيديولوجية، التحيز، المقالات المحررة.

(Analysis of the Biased Language...) Ghada Khaled Mohamed Atalla 